\title{
Karakteristik Fisikokimia Yogurt Tanpa Lemak dengan Penambahan Whey Protein Concentrate dan Gum Xanthan
}

\author{
Physicochemical Characteristics of Non-Fat Yogurt with Whey Protein Concentrate and Xanthan Gum \\ Addition
}

\author{
Mohamad Djali ${ }^{1 *}$, Syamsul Huda1, Lovita Andriani ${ }^{1}$ \\ ${ }^{1}$ Departemen Teknologi Industri Pangan, Fakultas Teknologi Industri Pertanian, \\ Universitas Padjadjaran, Jl. Raya Bandung Sumedang Km. 21, Sumedang, Jawa Barat, \\ Kode Pos 45363, Indonesia \\ *Email: agusdjali@yahoo.com
}

Tanggal submisi: 25 Februari 2017; Tanggal penerimaan: 31 Mei 2018

\begin{abstract}
ABSTRAK
Yogurt tanpa lemak memiliki kekuatan struktur yang rendah dan rentan terjadi pemisahan whey karena berkurangnya kandungan lemak. Pemisahan whey pada yogurt tidak disukai oleh konsumen. Tujuan penelitian ini adalah untuk mengevaluasi efek penambahan whey protein concentrate (WPC) dan gum xanthan terhadap karakteristik fisik, kimia sensori yogurt tanpa lemak. Karakteristik fisik dan kimia diuji menggunakan metode RAK, sedangkan karakteristik yogurt selama penyimpanan dingin 21 hari meliputi indeks sineresis dan organoleptik. Terdapat 6 perlakuan yaitu: A (susu segar $=$ kontrol 1$) ; \mathrm{B}$ (susu skim + skim milk powder $($ SMP) $3 \%=$ kontrol 2$) ; \mathrm{C}$ (susu skim + SMP $3 \%+$ WPC 1\%); D (susu skim + SMP 3\% + WPC 1,25\%); E (susu skim + SMP 3\% + WPC 0,5\% + gum xanthan 0,005\%); F (susu skim + SMP 3\% + WPC 0,5\% + gum xanthan 0,004\%). Kandungan lemak 0,12\%-0,14\% pada yogurt tanpa lemak dengan penambahan WPC dan kombinasi WPC-gum xanthan dapat meningkatkan firmness, cohesiveness, dan konsistensi dibandingkan kontrol 1 dan kontrol 2. Secara organoleptik, yogurt tanpa lemak dengan penambahan WPC dan kombinasi WPC-gum xanthan mendapatkan tingkat kesukaan panelis lebih tinggi untuk warna, rasa, aroma, dan kekentalan dibandingkan yogurt lemak utuh tanpa perlakuan. Yogurt tanpa lemak dengan penambahan WPC saja mendapatkan indeks sineresis lebih rendah dibandingkan perlakuan lainnya.
\end{abstract}

Kata kunci: Yogurt tanpa lemak; xanthan; whey protein concentrate

\section{ABSTRACT}

Non-fat yogurt exhibited weak body, poor texture, and whey separation because of reduction of fat. The separation of whey in yogurt is not desired by consumer. The aim of present study was to evaluate the effect of adding whey protein concentrate (WPC) and xanthan gum on physical, chemical and sensory properties of non-fat yogurt. Physical and chemical properties were tested using randomized block design whereas the yogurts properties during 21 days of cold storage included syneresis index and organoleptic. There were 6 treatments : A (full fat yogurt $=$ control 1); B (skim milk + skim milk powder (SMP) 3\% = control 2); C (skim milk + SMP 3\% + WPC 1\%); D (skim milk + SMP 3\% + WPC 1,25\%); E (skim milk + SMP 3\% + WPC 0,5\% + xanthan 0,005\%); F (skim milk + SMP 3\% + WPC 0,5\% + xanthan $0,004 \%$ ). The fat content $0,12 \%-0,14 \%$ of non-fat yogurt with the addition of WPC and blend of WPCxanthan could increased firmness, cohesiveness and consistency compared to control 1 and control 2. In the organoleptic properties, non-fat yogurt with the addition of WPC and blend of WPC-xanthan were gained color, flavor, aroma, and consistency of the panelists preferred higher than control yogurt. Non-fat yogurt with only addition of WPC gained the lowest syneresis index.

Keywords: Non-fat yoghurt; xanthan; whey protein concentrate 


\section{PENDAHULUAN}

Yogurt tanpa lemak menurut SNI (Badan Standardisasi Nasional, 2009) adalah yogurt dengan kandungan lemak maksimal $0,5 \%$ dengan total padatan bukan lemak minimal $8,2 \%$. Total padatan susu (termasuk lemak) pada pembuatan yogurt berkisar dari 9-20\%. Kandungan total padatan $12-14 \%$ sudah cukup untuk mendapatkan konsistensi yogurt yang baik (Tamime and Robinson, 2000). Berkurangnya komponen lemak dalam yogurt akan mengurangi total padatan yogurt sehingga berakibat pada kurang baiknya tekstur yogurt serta meningkatkan terjadinya pemisahan whey pada yogurt. Usaha memperbaiki kualitas yogurt tanpa lemak dapat dilakukan dengan penambahan bahan tambahan pangan lain dan atau modifikasi parameter proses produksi.

Usaha untuk mengganti lemak yang hilang tersebut umumnya dilakukan dengan menambahkan skim milk powder (SMP) atau sodium kaseinat. Tamime and Robinson (2000) menyatakan bahwa penambahan sejumlah bahan-bahan tersebut hingga mencapai total padatan yang hampir sama dengan yogurt lemak utuh memberikan tekstur yang berpasir, pengembangan asam yang berlebih dari fermentasi laktosa, firmness, dan sineresis yang tinggi. Penambahan SMP 3\% akan meningkatkan total padatan dan membantu menghasilkan yogurt dengan kualitas yang baik.

Yogurt tanpa lemak dapat diproduksi dengan menggantikan sebagian kandungan lemak pada susu dengan produk yang berkalori rendah yang disebut bahan pengganti lemak (Sandoval-Castilla et al, 2004). Bahan pengganti lemak merupakan bahan berbasis lemak, protein, atau karbohidrat yang dapat digunakan untuk menggantikan lemak pada produk pangan rendah lemak (Nikoofar et al., 2013). Salah satu bahan pengganti lemak adalah Whey protein concentrate (WPC) dan gum xanthan yang masing-masing merupakan bahan pengganti lemak berbasis protein dan karbohidrat (Aziznia et al., 2008; Nikoofar et al., 2013).

Whey protein concentrate (WPC) memiliki sifat fungsional yang dapat memperbaiki kualitas dalam pembuatan yogurt. Penggunaan WPC pada yogurt diketahui dapat menurunkan pemisahan whey, meningkatkan firmness, dan memperbaiki viskositas (Lucey et al., 1999). Penambahan WPC juga dapat meningkatkan nilai water holding capacity (WHC) dan menurunkan terjadinya sineresis pada yogurt (Chandan, 2007). Rekomendasi penambahan WPC pada yogurt paling tinggi adalah $2 \%$, dikarenakan konsentrasi yang lebih tinggi dapat memberikan flavor whey yang kurang disukai, menimbulkan penerimaan sensori tekstur yang kasar, dan mengurangi tingkat kecerahan pada yogurt (Chandan, 2007; Krzeminski et al., 2014; Tamime and Robinson, 2000). Penggunaan WPC dengan konsentrasi 0,$75 ; 1,5$; dan $2,0 \%$ pada yogurt tanpa lemak dapat meningkatkan firmness dan menurunkan sineresis untuk semua perlakuan (Aziznia, 2008). Penambahan 1\% WPC dapat meningkatkan viskositas dan WHC pada yogurt rendah lemak (Stijepić et al., 2012).

Stabiliser berupa hidrokoloid sering ditambahkan pada pembuatan yogurt untuk meningkatkan atau menjaga karakteristik yogurt yang diinginkan meliputi tekstur, penampakan, mouthfeel, viskositas, dan untuk mencegah pemisahan whey (Tamime \& Robinson, 2000). Dalam sistem emulsi pangan, kehadiran polisakarida dapat memberikan peran penting terhadap struktur dan stabilitas protein (Li et al., 2006). Kompleks polisakarida-protein diketahui dapat memperbaiki kemampuan emulsifikasi, stabilitas emulsi, dan tekstur produk rendah lemak. Gum xanthan termasuk dalam golongan hidrokoloid berbentuk polisakarida hasil fermentasi mikroba yang umum digunakan dalam industri pangan. Gum xanthan memiliki kelarutan dan stabilitas yang baik pada kondisi asam serta dapat memberikan kekentalan pada larutan dalam konsentrasi yang rendah (Glicksman, 2000). Penambahan gum xanthan dengan konsentrasi $0,005 \%$ dan $0,01 \%$ dapat meningkatkan viskositas yogurt lemak utuh dan tidak memengaruhi flavor yogurt (Hematyar et al., 2012). Kompleks isolat whey protein-gum xanthan dilaporkan dapat memperbaiki tekstur kue beku rendah lemak sehingga dapat digunakan sebagai bahan pengganti lemak (Laneuville et al, 2005).

Kemampuan campuran whey protein dan gum xanthan untuk memperbaiki tekstur tersebut menarik untuk diketahui aplikasinya pada produk lain yaitu yogurt tanpa lemak. Bahan pengganti lemak dapat memberikan fungsi struktural dan karakteristik sensori sehingga cocok untuk diaplikasikan dalam pembuatan yogurt, namun penambahan bahan tambahan tersebut harus dipelajari sebelumnya untuk mendapatkan rekomendasi aplikasi. Oleh sebab itu diperlukan penelitian untuk mengevaluasi efek penambahan WPC atau kombinasi WPC-gum xanthan terhadap karakteristik fisik, kimia, dan sensori yogurt tanpa lemak.

\section{METODE PENELITIAN}

Penelitian dilakukan dengan metode eksperimen menggunakan Rancangan Acak Kelompok (RAK) dengan 6 perlakuan dan 4 ulangan. Perlakuan yang ditetapkan yakni:

A: Susu segar (yogurt lemak utuh/kontrol 1);

B: Susu skim + SMP 3\% (kontrol 2);

C: Susu skim + SMP 3\% + WPC 1\%;

D: Susu skim + SMP 3\% + WPC 1,25\%;

E: Susu skim + SMP 3\% + WPC 0,5\% + xanthan 0,005\%;

F: Susu skim + SMP 3\% + WPC 0,5\% + xanthan $0,004 \%$.

Data hasil pengamatan dianalisis statistik dengan ANOVA dan untuk mengetahui tingkat perbedaan setiap 
perlakuan dilanjutkan uji Duncan pada taraf $5 \%$. Karakteristik yang diamati pada pengamatan utama ini adalah karakteristik fisik (firmness, cohesiveness, dan konsistensi) dan karakteristik kimia ( $\mathrm{pH}$, kadar protein, total asam tertitrasi, total padatan, dan kadar lemak). Pengamatan penunjang yaitu indeks sineresis dilakukan selama penyimpanan dingin 21 hari untuk semua sampel secara duplo serta karakteristik organoleptik menggunakan uji hedonik.

\section{Bahan}

Bahan-bahan yang digunakan dalam penelitian adalah: susu sapi segar yang berasal dari Fakultas Peternakan, Universitas Padjadjaran, WPC $80 \%$ produksi Saputo Cheese USA, dan starter yogurt Lactobacillus bulgaricus dan Streptococcus thermophilus hasil propagasi starter kering beku produksi Lactina Ltd Bulgaria.

\section{Alat}

Alat- alat yang digunakan adalah disc bow/ centrifuge Armfield FT15, inkubator BC240 Froilabo, texture analyzer TAXT (Stable Micro Systems Ltd, Syrrey, UK). Prosedur pembuatan yogurt percobaan adalah sebagai berikut: Susu sapi segar dipisahkan bagian krimnya dengan menggunakan cream separator sehingga didapatkan susu skim. Susu skim yang didapat, selanjutnya ditambahkan skim milk powder ( $3 \%$ ) pada suhu $45{ }^{\circ} \mathrm{C}$ dan dibagi ke dalam 5 bagian, 2 bagian ditambahkan WPC saja (perlakuan $C$ dan $D$ ), 2 bagian ditambahkan kombinasi WPC-gum xanthan (perlakuan E dan F) dan 1 bagian tanpa penambahan WPC maupun gum xanthan (perlakuan B), sedangkan satu perlakuan lainnya yaitu berasal dari susu segar langsung (perlakuan A). Setelah dilakukan pengadukan sampai homogen, susu kemudian dipasteurisasi pada suhu $85^{\circ} \mathrm{C}$ selama 30 menit dan diturunkan suhunya sampai $45{ }^{\circ} \mathrm{C}$. Inokulasi starter yogurt (4\%) menggunakan 2 bakteri yaitu $S$. thermophilus dan L. bulgaricus dilakukan pada suhu $42^{\circ} \mathrm{C}$ dalam cup plastik dan dilakukan inkubasi pada suhu $42^{\circ} \mathrm{C}$ selama 4 jam. Setelah proses inkubasi selesai, sampel kemudian disimpan dalam refrigerator untuk menghentikan proses fermentasi dan disimpan melewati satu malam pada suhu $4 \pm 1{ }^{\circ} \mathrm{C}$ untuk selanjutnya dilakukan analisis sampel.

\section{Pengamatan Karakteristik Fisik}

\section{Analisis tekstur yogurt dengan texture analyzer TAXT Express (Karaca dkk., 2013)}

Tekstur sampel diukur dengan alat Texture Analyzer TAXT (Stable Micro Systems Ltd Surrey, UK) menggunakan profile yogurt back-extrussion. Pengujian dilakukan melalui penetrasi probe silinder berdiameter 1 $\mathrm{cm}$ ke dalam sampel cup yogurt. Wadah yang digunakan pada penelitian adalah wadah cup plastik polypropylene yang berisi sampel yogurt dengan diameter $5 \mathrm{~cm}$ dan tinggi $4,5 \mathrm{~cm}$. Seluruh pengukuran dilakukan segera setelah sampel keluar dari refrigerator. Kecepatan probe pada saat pengujian diatur $1 \mathrm{~mm} / \mathrm{s}$, gaya pemicu $0,01 \mathrm{~N}$ dan masuk ke dalam sampel dengan kedalaman $10 \mathrm{~mm}$. Setelah probe mencapai kedalaman maksimum, probe akan bergerak keluar dari sampel sehingga respon yang diberikan sampel akan terbaca melalui grafik yang terbentuk. Parameter yang dihasilkan dari pengujian yaitu firmness, konsistensi, dan cohesiveness.

\section{Indeks sineresis (Shah et al., 2006)}

Pengukuran sineresis dilakukan dengan drainage method, sampel yogurt dikeluarkan dari ruang penyimpanan dingin dan whey yang keluar dialirkan. Sejumlah gel yogurt diambil dalam satu kali aksi menggunakan scoop es krim, yogurt yang berlebih dipisahkan dengan pisau sehingga didapat bentuk sampel hemispherical. Sampel yogurt kemudian ditempatkan di atas kertas saring Whatman no. 4 dan kemudian ditimbang dengan berat sekitar $40 \mathrm{~g}$. Volume $(\mathrm{mL})$ whey yang terpisah diukur setelah 15 menit pada suhu ruang $\left(25^{\circ} \mathrm{C}\right)$. Indeks sineresis dinyatakan sebagai persentase whey yang terpisah terhadap berat awal gel.

\section{Pengamatan Karakteristik Kimia}

Parameter kimia yang diamati meliputi $\mathrm{pH}$, jumlah total asam tertitrasi (dihitung sebagai asam laktat), kadar lemak metode soxhlet, dan kadar protein metode Mikro KjeldahL (AOAC, 1990) serta total padatan yogurt SNI 2981:2009 (Badan Standardisasi Nasional, 2009).

\section{Uji Organoleptik dengan Metode Hedonik}

Metode pengujian yang digunakan adalah uji hedonik dengan menggunakan panelis agak terlatih sebanyak 30 panelis. Panelis agak terlatih yaitu mahasiswa jurusan Teknologi Industri Pangan, fakultas Teknologi Industri Pertanian, Universitas Padjdjaran, yang telah mengambil mata kuliah Penilaian Sensori Pangan. Parameter yang diuji meliputi warna, rasa, aroma, dan kekentalan. Sampel disajikan secara acak dan panelis diminta pendapatnya tentang sampel yang disajikan sesuai dengan tingkat kesukaan/skala hedonik. Skala hedonik yang ditetapkan yaitu 5 (suka); 4 (agak suka); 3 (biasa); 2 (kurang suka); 1 (tidak suka).

\section{HASIL DAN PEMBAHASAN}

\section{Karakteristik Fisik}

\section{Firmness}

Firmness merupakan salah satu faktor utama dalam penilaian karakteristik fisik yogurt, firmness digunakan untuk mengukur gaya maksimum bahan pada deformasi tertentu (Li \& Yang, 2010 dikutip Karaca et al., 2013). Efek penambahan WPC dan kombinasi WPC dengan gum xanthan pada firmness yogurt tanpa lemak disajikan pada Tabel 1. Yogurt tanpa lemak dengan penambahan WPC $1,25 \%$ serta dengan penambahan kombinasi WPC-gum xanthan memberikan firmness berbeda nyata $(p<0,05)$ lebih tinggi dibandingkan 
Tabel 1. Firmness, cohesiveness, dan konsistensi yogurt tanpa lemak dengan penambahan WPC dan kombinasi WPC-gum xanthan

\begin{tabular}{lccc}
\hline \multicolumn{1}{c}{ Perlakuan } & Firmness $(\mathrm{g})$ & Cohesiveness $(\mathrm{g})$ & Konsistensi $(\mathrm{g} /$ sec) \\
\hline A (susu segar = kontrol 1) & $11,842^{\mathrm{c}} \pm 0,40$ & $5,819^{\mathrm{d}} \pm 0,71$ & $95,0112^{\mathrm{d}} \pm 3,02$ \\
B (susu skim + SMP 3\% = kontrol 2) & $20,661^{\mathrm{b}} \pm 1,18$ & $9,895^{\mathrm{c}} \pm 0,27$ & $130,697^{\mathrm{c}} \pm 2,74$ \\
C (susu skim + SMP 3\% + WPC 1\%) & $21,010^{\mathrm{b}} \pm 0,52$ & $11,386^{\mathrm{b}} \pm 1,09$ & $149,480^{\mathrm{b}} \pm 2,33$ \\
D (susu skim + SMP 3\% + WPC 1,25\%) & $23,679^{\mathrm{a}} \pm 0,41$ & $11,846^{\mathrm{b}} \pm 0,96$ & $165,298^{\mathrm{a}} \pm 3,22$ \\
E (susu skim + SMP 3\% + WPC 0,5\%: & $22,807^{\mathrm{a}} \pm 0,40$ & $14,381^{\mathrm{a}} \pm 0,74$ & $162,643^{\mathrm{a}} \pm 7,46$ \\
gum xanthan 0,005\%) & & $14,589^{\mathrm{a}} \pm 0,20$ & $154,226^{\mathrm{b}} \pm 4,12$ \\
F (susu skim + SMP 3\% + WPC 0,5\% : & $22,714^{\mathrm{a}} \pm 0,31$ & & \\
gum xanthan 0,004\%) & & & \\
\hline
\end{tabular}

Ket: Angka yang diikuti huruf yang sama tidak berbeda nyata menurut uji Duncan pada taraf $5 \%$

yogurt lemak utuh dan yogurt tanpa lemak tanpa penambahan WPC dan gum xanthan serta tidak berbeda nyata antar perlakuan sesamanya. Yogurt tanpa lemak dengan penambahan WPC $1 \%$ menghasilkan firmness yang tidak berbeda nyata dengan yogurt tanpa lemak tanpa penambahan WPC dan gum xanthan. Penambahan WPC sebanyak $1,25 \%$ pada pembuatan yogurt tanpa lemak mampu meningkatkan firmness. Adanya WPC dapat meningkatkan kapasitas pengikatan air dan fraksi volume protein yang teraggregasi sehingga struktur protein menjadi lebih padat.

Aggregat protein terbentuk dari interaksi antara misel kasein dan whey protein yang terdenaturasi melalui ikatan disulfida intermolekular yang hadir selama tahap awal koagulasi (J. A. Lucey et al., 1999). Pengurangan konsentrasi WPC menjadi $1 \%$, menurunkan firmness yogurt yang dihasilkan dan hasilnya tidak berbeda nyata dengan yogurt tanpa lemak tanpa penambahan WPC dan gum xanthan. Perlakuan dengan kombinasi penambahan WPC-gum xanthan memiliki firmness yang tidak berbeda nyata dengan yogurt tanpa lemak dengan penambahan WPC $1,25 \%$. Gum xanthan termasuk dalam golongan polisakarida netral non-adsorbing. Polisakarida netral non-adsorbing dengan kasein tidak terjadi interaksi elektrostatis. Gum xanthan dapat meningkatkan kekentalan dari fase kontinyu saat pembentukan gel selama fermentasi (Everett and McLeod, 2005).

Modifikasi proses seperti evaporasi dan penambahan SMP akan meningkatkan kandungan kasein dalam bahan baku susu dan turut meningkatkan jumlah total padatan sehingga dapat meningkatkan firmness yogurt (Walstra, 2006). Pemanasan susu pada suhu $85^{\circ} \mathrm{C}$ selama 30 menit memberi kecukupan denaturasi whey protein yang menyebabkan perubahan utama pada karakteristik pembentukan gel. Whey protein yang terdenaturasi dapat meningkatkan fraksi volume protein yang teraggregasi. Pemanasan juga dapat mengubah jumlah dan jenis ikatan antara partikel protein sehingga dapat meningkatkan tekstur yogurt. Kekokohan gel akan meningkat dengan menurunnya suhu selama proses pendinginan setelah proses fermentasi selesai. Jika gel terlalu hangat, struktur masih lemah. Struktur gel dapat rusak ketika terkena stress yang berlebih seperti pergerakan dan getaran (Lucey, 2004).

\section{Cohesiveness}

Cohesiveness dapat digambarkan sebagai kekuatan internal dari bahan pangan (Magenis et al., 2006). Efek penambahan WPC dan kombinasi WPC-gum xanthan pada cohesiveness yogurt tanpa lemak disajikan pada Tabel 1. Yogurt tanpa lemak dengan penambahan WPC serta kombinasi WPC-gum xanthan pada semua konsentrasi perlakuan memiliki cohesiveness berbeda nyata $(p<0,05)$ lebih tinggi dibandingkan sampel yogurt tanpa penambahan WPC dan gum xanthan. Penambahan kombinasi WPC-gum xanthan pada semua perlakuan memiliki cohesiveness berbeda nyata lebih tinggi $(p<0,05)$ dibandingkan dengan penambahan WPC saja, sedangkan perbedaan jumlah konsentrasi yang diberikan tidak berbeda nyata.

Adanya penambahan gum xanthan yang dikombinasikan dengan WPC mampu meningkatkan cohesiveness yogurt tanpa lemak dibandingkan dengan penambahan WPC saja. Gum xanthan tergolong hidrokoloid netral yang dapat meningkatkan kekentalan dari fase kontinyu dan dalam pembentukannya melibatkan jaringan polimer (Everett and McLeod, 2005). Kandungan lemak yang rendah pada yogurt tanpa lemak mendorong lebih banyak pembentukan jaringan protein yang tersusun terutama oleh ikatan misel kasein dibandingkan dengan yogurt lemak utuh dimana misel kasein banyak yang terikat dengan globula lemak yang kemudian berperan sebagai penguat struktur jaringan protein dalam yogurt(Sandoval-Castilla et al., 2004). Penambahan WPC sebanyak $1 \%$ dan $1,25 \%$ akan menambah jumlah protein sehingga meningkatkan nilai cohesiveness pada yogurt tanpa lemak dibandingkan sampel yogurt tanpa penambahan WPC.

\section{Konsistensi}

Konsistensi yogurt tanpa lemak dengan penambahan WPC dan kombinasi WPC-gum xanthan disajikan pada Tabel 1. Yogurt tanpa lemak dengan penambahan WPC serta kombinasi WPC-gum xanthan pada semua 
konsentrasi perlakuan memiliki konsistensi berbeda nyata $(p<0,05)$ lebih tinggi dibandingkan sampel yogurt tanpa penambahan WPC dan gum xanthan. Perlakuan dengan penambahan WPC $1,25 \%$ dan penambahan kombinasi WPC-gum xanthan $0,005 \%$ memiliki konsistensi yang berbeda nyata $(p<0,05)$ lebih tinggi dibandingkan perlakuan dengan penambahan WPC $1 \%$ dan penambahan kombinasi WPC-gum xanthan $0,004 \%$.

Perlakuan dengan konsentrasi gum xanthan yang lebih besar akan memberikan konsistensi yogurt yang lebih tinggi. Gum xanthan memiliki kemampuan mengikat air yang tinggi dalam konsentrasi yang rendah yang ditunjukkan pada perlakuan dengan penambahan gum xanthan $0,005 \%$ memberikan konsistensi yogurt lebih tinggi dibandingkan dengan penambahan 0,004\%. Konsistensi yogurt sejalan dengan nilai firmness, perlakuan dengan nilai firmness yang tinggi akan menghasilkan konsistensi yang tinggi pula. Jumlah protein yang meningkat melalui penambahan SMP dan WPC dapat memengaruhi pembentukan koagulum sehingga yogurt memiliki konsistensi yang lebih tinggi. WPC lebih efektif dalam meningkatkan konsistensi yogurt dibandingkan SMP dalam total padatan yang sama (Akalın et al., 2012).

Pemanasan pada suhu $85{ }^{\circ} \mathrm{C}$ selama 30 menit yang dilakukan dalam penelitian ini dapat meningkatkan sifat hidrofilik protein sehingga dapat meningkatkan konsistensi yogurt. Penambahan SMP dan pemekatan susu melalui pasteurisasi mampu memperbaiki konsistensi yogurt secara signifikan. Selain protein, hal tersebut juga turut meningkatkan kandungan padatan dari komponen susu lainnya, sehingga dapat meningkatkan konsistensi yogurt.

\section{Indeks Sineresis}

Secara umum terjadi peningkatan indeks sineresis pada semua perlakuan selama penyimpanan 21 hari. Yogurt tanpa lemak dengan penambahan WPC serta kombinasi WPC-gum xanthan pada semua konsentrasi perlakuan memiliki indeks sineresis lebih rendah dibandingkan sampel yogurt lemak utuh yang terbuat hanya dari susu segar tanpa bahan tambahan apapun. Penambahan total padatan terutama protein dapat memperbaiki tekstur dan mengurangi sineresis (Lee and Lucey, 2010).

Sineresis terjadi karena adanya penyusutan struktur tiga dimensi dari jaringan protein yang menyebabkan turunnya kekuatan ikatan whey protein sehingga keluar dari yogurt (Bahrami et al., 2013). Penambahan total padatan terutama protein dapat memperbaiki tekstur dan mengurangi sineresis (Lee \& Lucey, 2010). Sineresis terendah dicapai pada perlakuan dengan penambahan WPC saja $1,25 \%$ dan di bawahnya adalah dengan penambahan WPC $1 \%$. Whey protein mengandung ikatan disulfida intramolekuler yang dapat menstabilkan struktur yogurt. Salah satu komponen utama whey protein yaitu $\beta$-Laktoglobulin memiliki grup sulfhydril yang menjadi lebih aktif saat terjadi denaturasi protein dan kemudian membentuk interaksi sulfhydril-disulfida dengan sesamanya dan protein lainnya (Isleten and KaragulYuceer, 2006). Perlakuan dengan penambahan kombinasi WPC-gum xanthan pada semua konsentrasi perlakuan, memberikan hasil sineresis yogurt yang meningkat dibandingkan perlakuan dengan penambahan WPC saja namun masih dibawah sampel yogurt lemak utuh yang terbuat hanya dari susu segar tanpa bahan tambahan apapun.

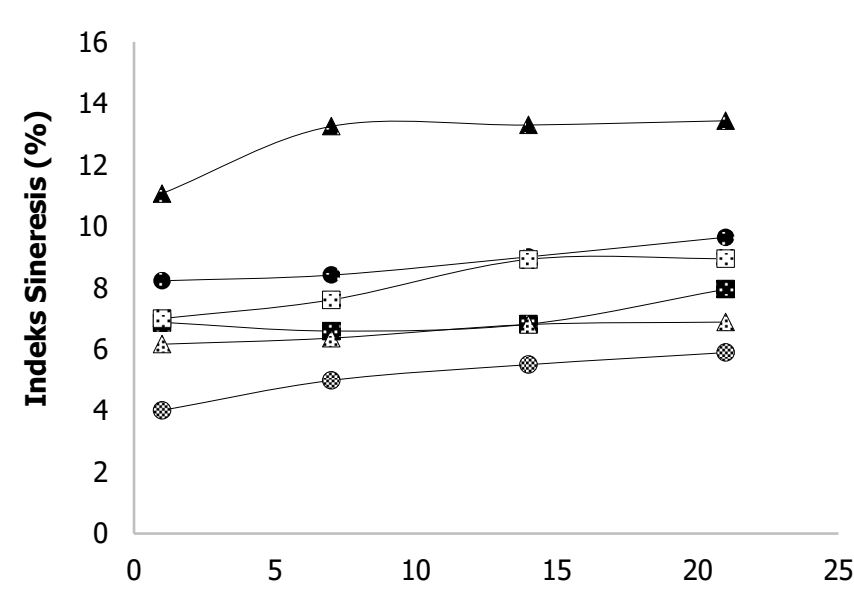

Hari Penyimpanan

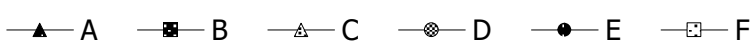

Ket: Indeks sineresis yogurt dari perlakuan A: susu segar (kontrol 1); B: susu skim + SMP 3\% (kontrol 2); C: susu skim + SMP 3\% + WPC 1\%; D: susu skim + SMP 3\% + WPC 1,25\%; E: susu skim + SMP 3\% + WPC $0,5 \%$ + gum xanthan 0,005\%; F: susu skim + SMP $3 \%$ + WPC $0,5 \%+$ gum xanthan $0,004 \%$

Gambar 1. Grafik indeks sineresis yogurt tanpa lemak dengan penambahan WPC dan kombinasi WPC-gum xanthan selama penyimpanan 21 hari pada $4^{\circ} \mathrm{C}$

Penambahan konsentrasi gum xanthan yang lebih tinggi memiliki kecenderungan sineresis yang lebih tinggi seperti terlihat pada Gambar 1. Hal ini dapat disebabkan oleh terjadi deplesi flokulasi. Deplesi menyebabkan turunnya gaya tolak menolak. Pelarut di antara partikel gum xanthan memiliki kecenderungan berdifusi keluar untuk mengurangi gradien konsentrasi gum xanthan sehingga menyebabkan droplet menjadi aggregat. Aggregat terbentuk akibat munculnya tekanan osmosis karena adanya gradien konsentrasi gum xanthan di antara daerah inter-partikel dan fase kontinyu. Ikatan yang terbentuk karena deplesi bersifat reversible dan fleksibel (Sun, 2007). Penambahan stabiliser memiliki kecenderungan dalam memproduksi asam lebih lambat dalam proses fermentasi yang dapat menyebabkan pembentukan struktur yang kurang sempurna. Gum xanthan bersama guar dan locust bean gum tergolong dalam polisakarida netral non-adsorbing. Pada penambahan gum xanthan tidak terjadi interaksi antara gum xanthan dengan kasein. Gum xanthan dapat meningkatkan kekentalan dari fase kontinyu saat pembentukan gel selama fermentasi (Everett and McLeod, 2005). 


\section{Karakteristik Kimia}

\section{pH}

Yogurt tanpa lemak dengan penambahan WPC 1\% dan $1,25 \%$ memberikan $\mathrm{pH}$ yang berbeda nyata $(p<0,05)$ lebih rendah dibandingkan yogurt lemak utuh, sedangkan penambahan kombinasi WPC-gum xanthan pada semua konsentrasi perlakuan tidak berbeda nyata dengan sampel yogurt tanpa penambahan WPC dan xanthan. Nilai $\mathrm{pH}$ dengan penambahan kombinasi WPCgum xanthan pada semua konsentrasi perlakuan berbeda nyata $(p<0,05)$ lebih tinggi dibandingkan sampel dengan penambahan WPC $1,25 \%$, sedangkan antar perlakuan penambahan kombinasi WPC-gum xanthan memiliki pH yang tidak berbeda nyata.

Yogurt yang diujikan memiliki kisaran $\mathrm{pH} 4,39-4,47$. Nilai $\mathrm{pH}$ yang lebih rendah pada perlakuan dengan penambahan WPC saja $1 \%$ dan $1,25 \%$ dapat disebabkan oleh pengaruh penambahan SMP dan WPC. Peningkatan total padatan dengan penambahan SMP turut meningkatkan jumlah laktosa pada bahan baku susu yang digunakan. Laktosa merupakan nutrisi bagi bakteri yogurt dalam pertumbuhannya, sehingga ketika jumlah laktosa meningkat, produksi asam laktat dari bakteri yogurt dapat menjadi lebih tinggi dibandingkan yogurt dari susu segar.

Secara umum, WPC memiliki kapasitas buffering yang lebih rendah dibandingkan kasein sehingga nilai $\mathrm{pH}$ yogurt menjadi lebih rendah (Akalın et al., 2012). Yogurt dengan penambahan kombinasi WPC-gum xanthan pada semua konsentrasi perlakuan memiliki $\mathrm{pH}$ yogurt yang lebih tinggi dibandingkan perlakuan dengan penambahan WPC saja $1,25 \%$. Hal tersebut dapat disebabkan oleh adanya penambahan gum xanthan pada perlakuan. Penambahan stabiliser seperti gum xanthan dalam pembuatan yogurt memiliki kecenderungan dalam produksi asam yang lebih lambat karena sistem yang lebih kental dapat menurunkan reaksi yang terjadi antara mikroorganisme starter yogurt dengan laktosa (Alakali et al., 2008).

\section{Protein}

Yogurt tanpa lemak dengan penambahan WPC serta kombinasi WPC dan xanthan pada semua konsentrasi perlakuan memiliki kandungan protein yang berbeda nyata $(p<0,05)$ lebih tinggi dibandingkan sampel yogurt tanpa penambahan WPC dan xanthan. Penambahan WPC $1,25 \%$ memiliki kandungan protein nyata lebih tinggi dibandingkan penambahan WPC $1 \%$, sedangkan perlakuan dengan penambahan kombinasi WPC-gum xanthan pada semua konsentrasi perlakuan nyata lebih rendah dibandingkan dengan penambahan WPC saja $1 \%$ dan antar perlakuan dengan penambahan kombinasi WPC-gum xanthan pada semua konsentrasi perlakuan tidak berbeda nyata. Kandungan protein yogurt hasil penelitian berkisar dari 3,24\%-4,14\% dan persyaratan minimal kandungan protein yogurt menurut SNI 2981:2009 (Badan Standardisasi Nasional, 2009) adalah $2,7 \%$ sehingga semua perlakuan memenuhi persyaratan tersebut.

Kandungan protein yogurt yang dihasilkan, berbeda nyata pada semua perlakuan kecuali perlakuan dengan penambahan kombinasi WPC-gum xanthan. Perbedaan ini berkaitan dengan bahan baku susu yang digunakan dalam persiapan pembuatan yogurt. Penambahan WPC yang diberikan pada perlakuan berbanding lurus dengan kandungan protein yogurt yang dihasilkan. Peningkatan kandungan protein kasein pada susu untuk pembuatan yogurt dapat membantu meningkatkan firmness dan konsistensi. Matriks pada yogurt tersusun dari partikel kasein sehingga peningkatan jumlah partikel berpengaruh secara langsung pada perbaikan firmness dan konsistensi. Peningkatan kandungan WPC dan penurunan rasio kasein terhadap whey protein dapat meningkatkan firmness gel jika dilakukan perlakuan pemanasan dimana diperlukan untuk mendenaturasi whey protein agar terjadi ikatan dengan misel kasein (John A. Lucey, 2004).

\section{Total Asam Tertitrasi}

Total asam tertitrasi pada yogurt yang diujikan berkisar 0,98\%-1,31\% dimana menurut persyaratan SNI 2981:2009 (Badan Standardisasi Nasional, 2009) adalah $0,5 \%-2,0 \%$ sehingga semua perlakuan pada penelitian ini telah memenuhi syarat tersebut. Tabel 2 menunjukkan bahwa penambahan WPC serta kombinasi WPC-gum xanthan pada semua konsentrasi perlakuan memiliki total asam tertitrasi berbeda nyata $(p<0,05)$ lebih tinggi dibandingkan yogurt lemak utuh, namun

Tabel 2. Karakteristik kimia yogurt tanpa lemak dengan penambahan WPC dan kombinasi WPC-gum xanthan

\begin{tabular}{|c|c|c|c|c|c|}
\hline Perlakuan & $\mathrm{pH}$ & Protein (\%) & TAT $(\%)$ & Total Padatan (\%) & Lemak (\%) \\
\hline A (susu segar = kontrol 1 ) & $4,47^{a} \pm 0,03$ & $3,24^{e} \pm 0,06$ & $0,98^{b} \pm 0,04$ & $12,97^{\mathrm{ab}} \pm 0,39$ & $3,58^{a} \pm 0,17$ \\
\hline B (susu skim + SMP $3 \%=$ kontrol 2 ) & $4,43^{a b c} \pm 0,03$ & $3,67^{d} \pm 0,05$ & $1,30^{\mathrm{a}} \pm 0,13$ & $11,60^{c} \pm 0,09$ & $0,19^{b} \pm 0,03$ \\
\hline \multirow{2}{*}{$\begin{array}{l}\text { C (susu skim + SMP } 3 \%+\text { WPC 1\%) } \\
\text { D (susu skim + SMP 3\% + WPC } \\
1,25 \%)\end{array}$} & $4,41^{b c} \pm 0,03$ & $3,97^{b} \pm 0,07$ & $1,36^{\mathrm{a}} \pm 0,04$ & $12,46^{b} \pm 0,20$ & $0,14^{b} \pm 0,01$ \\
\hline & $4,39^{c} \pm 0,02$ & $4,14^{a} \pm 0,06$ & $1,36^{a} \pm 0,03$ & $13,18^{a} \pm 0,72$ & $0,13^{b} \pm 0,02$ \\
\hline $\begin{array}{l}\text { E (susu skim + SMP 3\% + WPC 0,5\%: } \\
\text { gum xanthan 0,005\%) }\end{array}$ & $4,44^{a b} \pm 0,03$ & $3,75^{c} \pm 0,02$ & $1,33^{\mathrm{a}} \pm 0,04$ & $12,43^{b} \pm 0,21$ & $0,12^{b} \pm 0,03$ \\
\hline $\begin{array}{l}\text { F (susu skim + SMP 3\% + WPC 0,5\%: } \\
\text { gum xanthan 0,004\%) }\end{array}$ & $4,44^{\mathrm{ab}} \pm 0,04$ & $3,76^{c} \pm 0,03$ & $1,31^{a} \pm 0,07$ & $12,42^{b} \pm 0,04$ & $0,12^{b} \pm 0,03$ \\
\hline
\end{tabular}

Ket: Angka yang diikuti huruf yang sama tidak berbeda nyata menurut uji Duncan pada taraf $5 \%$ 
tidak berbeda nyata dengan yogurt tanpa lemak tanpa penambahan WPC dan gum xanthan.

Yogurt lemak utuh yang terbuat hanya dari susu segar tanpa perlakuan apapun memiliki konsentrasi kasein lebih kecil dan konsentrasi lemak lebih tinggi dibandingkan perlakuan lainnya. Peningkatan konsentrasi kasein dapat meningkatkan keasaman yogurt sedangkan globula lemak sulit berkontribusi pada keasaman sehingga perlakuan tersebut memiliki total asam tertitrasi lebih kecil dibandingkan perlakuan lainnya (Walstra, 2006).

\section{Total Padatan}

Persyaratan minimal total padatan yogurt menurut SNI 2981:2009 (Badan Standardisasi Nasional, 2009) adalah $8,2 \%$. Jumlah total padatan pada semua perlakuan memenuhi persyaratan SNI dimana jumlahnya berkisar dari 11,60\%-13,18\%. Yogurt tanpa lemak dengan penambahan WPC serta kombinasi WPC-gum xanthan pada semua konsentrasi perlakuan memiliki total padatan berbeda nyata $(p<0,05)$ lebih tinggi dibandingkan yogurt tanpa lemak tanpa penambahan WPC dan xanthan, namun tidak berbeda nyata dengan yogurt lemak utuh. Penambahan WPC 1,25\% memiliki total padatan berbeda nyata $(p<0,05 \%)$ lebih tinggi dengan perlakuan penambahan WPC $1 \%$ serta kombinasi WPC-gum xanthan pada semua perlakuan, sedangkan antar perlakuan penambahan WPC $1 \%$ serta kombinasi WPCgum xanthan pada semua perlakuan tidak berbeda nyata.

Penambahan padatan bukan lemak seperti SMP, WPC, maupun stabilizer seperti gum xanthan dapat meningkatkan total padatan sehingga dapat memperbaiki karakteristik yogurt yang dihasilkan. Jumlah total padatan antara perlakuan yogurt lemak utuh dan yogurt tanpa lemak dengan penambahan WPC 1,25\% tidak berbeda nyata, namun perlakuan yogurt tanpa lemak dengan penambahan WPC $1,25 \%$ memiliki firmness dan konsistensi yang lebih tinggi seperti yang dijelaskan sebelumnya. Hal ini dikarenakan, pada jumlah total padatan yang sama, perlakuan dengan penambahan WPC memiliki kadar protein yang lebih tinggi dan kadar lemak yang lebih rendah dibandingkan perlakuan yogurt lemak utuh sehingga memengaruhi karakteristik yogurt yang dihasilkan. Berdasarkan total padatan, kandungan total padatan sejumlah $12-14 \%$ sudah cukup untuk mendapatkan konsistensi yogurt yang baik (Tamime \& Robinson, 2000).

\section{Lemak}

Yogurt tanpa lemak pada semua perlakuan memiliki kandungan lemak berbeda nyata $(p<0,05)$ lebih rendah dibandingkan yogurt lemak utuh, sedangkan antar perlakuan yogurt tanpa lemak pada semua perlakuan tidak berbeda nyata. Kandungan lemak yogurt tanpa lemak menurut SNI 2981:2009 (Badan Standardisasi Nasional, 2009) maksimal mengandung lemak 0,5\% sedangkan yogurt konvensional minimal mengandung lemak $3 \%$. Perlakuan $B, C, D, E$, dan $F$ tergolong pada yogurt tanpa lemak dengan kisaran kandungan lemak yang dimiliki dari $0,12 \%-0,19 \%$, sedangkan perlakuan A dengan kandungan lemak 3,58\% tergolong pada yogurt konvensional.

Pada perlakuan selain yogurt lemak utuh, yogurt dibuat dari bahan baku susu skim segar yang telah dipisahkan bagian krimnya dari susu segar, sedangkan yogurt lemak utuh dari perlakuan A dibuat dari susu segar dengan kandungan lemak yang utuh. Penambahan SMP, WPC, maupun gum xanthan relatif tidak menambah kandungan lemak yogurt karena bahan-bahan tersebut relatif tidak mengandung lemak. Pengurangan kadar lemak pada susu dalam pembuatan yogurt akan menurunkan total padatan sehingga mengurangi karakteristik tekstural yogurt. Penambahan bahan padatan non lemak terutama protein sampai mencapai total padatan $12 \%-14 \%$ akan mampu meningkatkan karakteristik fisik yogurt.

\section{Karakteristik Organoleptik}

Yogurt tanpa lemak dengan penambahan WPC 1\% mendapatkan tingkat kesukaan warna tertinggi. Yogurt dengan konsentrasi lemak yang lebih tinggi akan lebih berwarna kekuningan akibat adanya pigmen karoten dan xantofil yang larut dalam lemak (Chandan, 2007), sedangkan pada yogurt tanpa lemak menghasilkan warna yang lebih putih yaitu putih susu.

Tingkat kesukaan rasa yogurt tanpa lemak dengan penambahan WPC $1 \%$ dan sampel yogurt tanpa lemak dengan penambahan kombinasi WPC-xanthan 0,005\% mendapatkan nilai tertinggi dibandingkan perlakuan lainnya. Yogurt yang dibuat dalam penelitian ini, tidak

Tabel 3. Karakteristik organoleptik yogurt tanpa lemak dengan penambahan WPC dan kombinasi WPC-gum xanthan

\begin{tabular}{lcccc}
\hline \multicolumn{1}{c}{ Perlakuan } & Warna & Rasa & Aroma & Kekentalan \\
\hline A (susu segar = kontrol 1) & $4,0 \pm 0,83$ & $3,3 \pm 1,12$ & $3,5 \pm 0,97$ & $3,0 \pm 0,93$ \\
B (susu skim + SMP 3\% = kontrol 2) & $4,0 \pm 0,87$ & $3,4 \pm 0,93$ & $3,5 \pm 0,86$ & $3,2 \pm 1,10$ \\
C (susu skim + SMP 3\% + WPC 1\%) & $4,1 \pm 0,80$ & $3,5 \pm 1,07$ & $3,5 \pm 0,90$ & $3,7 \pm 1,06$ \\
D (susu skim + SMP 3\% + WPC 1,25\%) & $4,0 \pm 0,81$ & $3,2 \pm 1,06$ & $3,6 \pm 0,89$ & $3,7 \pm 1,02$ \\
E (susu skim + SMP 3\% + WPC 0,5\% : & $4,0 \pm 0,81$ & $3,5 \pm 0,94$ & $3,7 \pm 0,78$ & $3,8 \pm 0,92$ \\
$\quad$ gum xanthan 0,005\%) & & & \\
F (susu skim + SMP 3\% + WPC 0,5\% : & $4,0 \pm 0,78$ & $3,4 \pm 0,88$ & $3,5 \pm 1,01$ & $3,8 \pm 1,05$ \\
$\quad$ gum xanthan 0,004\%) & & & & \\
\hline
\end{tabular}


ditambahkan gula, sehingga memiliki rasa plain. Pada yogurt lemak utuh, terdapat after taste dari lemak yang mungkin kurang disukai panelis dibandingkan yogurt tanpa lemak yang tidak menimbulkan after taste.

Yogurt merupakan produk yang memiliki aroma khas yang berbeda dari produk awalnya yaitu susu dimana merupakan hasil fermentasi bakteri asam laktat. Aroma yogurt yang mendapatkan tingkat kesukaan panelis yang tinggi adalah sampel yogurt dengan penambahan kombinasi WPC-gum xanthan $0,004 \%$ diikuti yogurt dengan penambahan WPC saja $1,25 \%$.

Perlakuan dengan penambahan WPC dan kombinasi WPC-gum xanthan pada yogurt tanpa lemak berkontribusi terhadap semakin tingginya tingkat kesukaan kekentalan pada panelis. Kandungan lemak yang rendah dan penambahan SMP serta WPC pada yogurt tanpa lemak mendorong lebih banyak pembentukan jaringan protein yang tersusun terutama oleh ikatan misel kasein dibandingkan dengan yogurt lemak utuh dimana misel kasein banyak yang terikat pada globula lemak, yang kemudian berperan sebagai penguat struktur jaringan protein dalam yogurt (Sandoval-Castilla et al., 2004). Penambahan gum xanthan dapat meningkatkan kekentalan dari fase kontinyu, sehingga turut berkontribusi dalam meningkatkan kekentalan yogurt tanpa lemak.

\section{KESIMPULAN}

Penambahan WPC dan kombinasi WPC-gum xanthan mampu meningkatkan firmness, cohesiveness, dan konsistensi yogurt tanpa lemak, bahkan lebih tinggi dibandingkan yogurt kontrol dengan lemak yang utuh. Yogurt tanpa lemak dengan penambahan WPC saja memiliki indeks sineresis lebih rendah dibandingkan perlakuan lainnya. Yogurt tanpa lemak dengan penambahan WPC dan kombinasi WPC-gum xanthan mendapatkan tingkat kesukaan panelis lebih tinggi untuk warna, rasa, aroma, dan kekentalan dibandingkan yogurt lemak utuh tanpa perlakuan.

\section{DAFTAR PUSTAKA}

Akalın, A. S., Unal, G., Dinkci, N., \& Hayaloglu, A. A. (2012). Microstructural, textural, and sensory characteristics of probiotic yogurts fortified with sodium calcium caseinate or whey protein concentrate. Journal of Dairy Science, 95(7), 3617-3628. https://doi.org/10.3168/jds.2011-5297

Alakali, J. S., Okonkwo, T. M., \& Iordye, E. M. (2008). Effect of stabilizers on the physico-chemical and sensory attributes of thermized yoghurt. African Journal of Biotechnology, 72 , 158-163. https://doi.org/10.3390/foods3020318

AOAC. (1990). AOAC Official Methods of Analysis. Association of Official Agricultural Chemists. Washington, D.C., 15th(Volume 1), 136-138.

Aziznia, S., Khosrowshahi, A., Madadlou, A., \& Rahimi, J. (2008). Whey Protein Concentrate and Gum Tragacanth as Fat Replacers in Nonfat Yogurt: Chemical, Physical, and Microstructural Properties. Journal of Dairy Science, 91(7), 2545-2552. https://doi.org/10.3168/jds.2007-0875
Badan Standardisasi Nasional. (2009). Yogurt. Standar Nasional Indonesia, (SNI 2981:2009).

Bahrami, M., Ahmadi, D., Alizadeh, M., \& Hosseini, F. (2013). Physicochemical and sensorial properties of probiotic yogurt as affected by additions of different types of hydrocolloid. Korean Journal for Food Science of Animal Resources, 33(3), 363-368. https://doi.org/10.5851/kosfa.2013.33.3.363

Chandan, R. C. (2007). Manufacturing Yogurt and Fermented Milks. Manufacturing Yogurt and Fermented Milks. USA: Blackwell https://doi.org/10.1002/9780470277812

Publishing.

Everett, D. W., \& McLeod, R. E. (2005). Interactions of polysaccharide stabilisers with casein aggregates in stirred skim-milk yoghurt. International Dairy Journal, 15(11), 1175-1183. https://doi.org/10.1016/j.idairyj.2004.12.004

Glicksman, M. (2000). Food Hydrocolloids. Vol 1.CRC Press Inc., Boca Raton, FL.

Hematyar, N., Samarin, A. M., Poorazarang, H., \& Elhamirad, A. H. (2012). Effect of gums on yogurt characteristics. World Applied Sciences Journal, 20(5), 661-665. https://doi.org/10.5829/idosi.wasj.2012.20.05.2353

Isleten, M., \& Karagul-Yuceer, Y. (2006). Effects of Dried Dairy Ingredients on Physical and Sensory Properties of Nonfat Yogurt. Journal of Dairy Science, 89(8), 2865-2872. https://doi.org/10.3168/jds.S0022-0302(06)72559-0

Karaca, O. B., Saydam, I. B., Kahyaoglu, T., Unal, E., Erginkaya, Z., \& Guven, M. (2013). Textural Properties and Survival of Lactobacillus acidophilus, Streptococcus thermophilus and Lactobacillus delbrueckii subsp. Bulgaricus of Probiotic Set Yogurts Produced by Prebiotic Stabilizers and Different Molasses Types. Journal of Food Agriculture and Environment 11(3): 199-203.

Krzeminski, A., Prell, K. A., Busch-Stockfisch, M., Weiss, J., \& Hinrichs, J. (2014). Whey protein-pectin complexes as new texturising elements in fat-reduced yoghurt systems. International Dairy Journal, 36(2), 118-127. https://doi.org/10.1016/j.idairyj.2014.01.018

Laneuville, S. I., Paquin, P., \& Turgeon, S. L. (2005). Formula Optimization of a Low-fat Food System Containing Whey Protein Isolate- Xanthan Gum Complexes as Fat Replacer. Journal of Food Science, 70(8), s513-s519. https://doi.org/10.1111/j.1365-2621.2005.tb11527.x

Lee, W. J., \& Lucey, J. A. (2010). Formation and physical properties of yogurt. Asian-Australasian Journal of Animal Sciences, 23(9), 1127-1136. https://doi.org/10.5713/ajas.2010.r.05

Li, J., Ould Eleya, M. M., \& Gunasekaran, S. (2006). Gelation of whey protein and xanthan mixture: Effect of heating rate on rheological properties. Food Hydrocolloids, 20(5), 678686. https://doi.org/10.1016/j.foodhyd.2005.07.001

Lucey, J. A. (2004). Cultured dairy products: An overview of their gelation and texture properties. International Journal of Dairy Technology, 57(2-3), 77-84. https://doi.org/10.1111/j.1471-0307.2004.00142.x

Lucey, J. A., Munro, P. A., \& Singh, H. (1999). Effects of heat treatment and whey protein addition on the rheological properties and structure of acid skim milk gels. International Dairy Journal, g(3-6), 275-279. https://doi.org/10.1016/S0958-6946(99)00074-6

Magenis, B.R., Prudencio, E.S., Amboni R.D.M.C., Cerquierra, N.G.Jr., Olivierra, R.V.B., Soldi, V., \& Benedet, H.D. (2006). Compositional and Physical Properties of Yogurt Manufactured from Whey and Cheese Concentrated by Ultrafiltration. International Journal of Food Science and 
Technology. 41(5), 560-568. https://doi.org/10.1111/j.1365-2621.2005.01100.x

Nikoofar, E., Hojjatoleslamy, M., Shakerian, A., \& Molavi, H. (2013). Surveying the Effect of Oat Beta Glucan As a Fat Replacer on Rheological and Physicochemical Characteristics of Non Fat Set Yoghurt. International Journal of Farming and Allied Sciences, 2(20), 861-865.

Sandoval-Castilla, O., Lobato-Calleros, C., Aguirre-Mandujano, E., \& Vernon-Carter, E. J. (2004). Microstructure and texture of yogurt as influenced by fat replacers. International Dairy Journal, 14(2), 151-159. https://doi.org/10.1016/S09586946(03)00166-3

Shah, P. N., Sherkath, F., \& Amatayakul, T. (2006). Syneresis in set yoghurt as affected by EPS starter culture and level of solids. International Journal of Dairy Technology, 59(3), 216-221. https://doi.org/dx.doi.org/10.1111/j.14710307.2006.00264.x

Stijepić, M., Đurđević-Milošević, D., \& Glušac, J. (2012). Production of Low Fat Yoghurt Enriched With Different Functional Ingredients. Quality of Life (Banja Luka) APEIRON, 5(1-2), 5-12. https://doi.org/10.7251/QOL1201005S

Sun Changhui, Gunasekaran, S., \& Richards, M. (2007). Effect of Xanthan Gum on Physicochemical Properties of Whey Protein Isolate Stabilized Oil-in-Water Emulsions. Food Hydrocolloids. 21: 555-564. https://doi.org/10.1016/j.foodhyd.2006.06.003

Tamime, A. Y., \& Robinson, R. K. (2000). Yoghurt Science and Technology (2nd ed.). Cambridge England: Woodhead Publishing Limited.

Walstra, P. (1998). Relation Between Structure and Texture of Cultured Milk Products. In: Texture of Fermented Milk Products and Dairy Desserts. Special Issue 9802. International Dairy Federation, Brussels. pp. 9-15. 